\title{
Grafting for Root-knot Nematode Control and Yield Improvement in Organic Heirloom Tomato Production
}

\author{
Charles E. Barrett ${ }^{1}$ and Xin $\mathrm{Zhao}^{2,4}$ \\ Horticultural Sciences Department, University of Florida, 1301 Fifield Hall, \\ Gainesville, FL 32611-0690
}

Robert McSorley
Entomology and Nematology Department, University of Florida, Gainesville,
FL 32611-0620

Additional index words. Solanum lycopersicum, S. lycopersicum $\times$ S. habrochaites, Meloidogyne spp., root galling, rootstock, scion

\begin{abstract}
Organic heirloom tomatoes (Solanum lycopersicum L.) are difficult to grow in Florida as a result of root-knot nematodes (Meloidogyne spp.) (RKN) and hot, humid growing conditions. Although grafting with resistant rootstocks has been shown effective for RKN management in tomato production, little research has been conducted on grafted heirloom tomatoes under Florida conditions. In this 2-year study, two susceptible heirloom tomato scions, 'Brandywine' and 'Flamme', were grafted onto two hybrid rootstocks, i.e., interspecific tomato hybrid rootstock 'Multifort' $(S$. lycopersicum $\times S$. habrochaites) and tomato hybrid rootstock 'Survivor' (S. lycopersicum). Non-grafted and self-grafted scions were used as controls. Three field trials were conducted including the 2010 and 2011 organic field trials as well as a transitional organic field trial in 2011. There was a lack of RKN pressure in the organic field in 2010. In 2011, the RKN population was higher in the transitional field than the organic field, whereas grafting with hybrid rootstocks significantly reduced root galling $(P \leq 0.0001)$ in both fields. In the organic field, the hybrid rootstocks performed similarly and significantly reduced root galling compared with the non-grafted and self-grafted scions by $\approx \mathbf{8 0 . 8 \%} \%$. In the transitional field, compared with non-grafted scions, the root galling reduction by 'Survivor' (97.1\%) was significantly greater than that by 'Multifort' $(57.6 \%)$. In general, tomato plants grafted onto 'Multifort' tended to be more vigorous than all other treatments. There was no clear relationship between root galling and tomato yields. Grafting did not significantly affect the total marketable yield for the scion 'Flamme' in both years. Total marketable yield was similar among treatments in 2010 but varied in 2011 for the scion 'Brandywine'. In 2011, the non-grafted 'Brandywine' and 'Brandywine' grafted to 'Survivor' produced significantly higher $(P<0.05)$ yields than other treatments in the organic field. However, in the transitional field, 'Brandywine' grafted to 'Multifort' resulted in significantly higher $(P<0.05)$ yields than the non- and self-grafted 'Brandywine' treatments. Grafting with appropriate rootstocks may play an effective role in RKN management during the transition to organic production when high populations of nematodes are present.
\end{abstract}

Modern tomato breeding has led to improvements in postharvest attributes including shelf life, but this has come with a

Received for publication 23 Nov. 2011. Accepted for publication 13 Mar. 2012.

This research was funded in part by Southern Region Sustainable Agriculture Research and Education (SARE) Graduate Student Grant awarded to Charles Barrett.

We thank Takii Seeds USA for providing 'Survivor' rootstock seeds and De Ruiter Seeds Inc. for providing 'Multifort' rootstock seeds. We also thank Buck Nelson and crew at the PSREU, Citra, FL, for support and comments concerning the field trials for this article.

${ }^{1}$ Graduate Research Assistant.

${ }^{2}$ Assistant Professor.

${ }^{3}$ Professor.

${ }^{4}$ To whom reprint requests should be addressed; e-mail zxin@ufl.edu. ameliorate soil conditions between planting of susceptible crops.

Organic growers often face pest and disease challenges with few effective control methods, making organic heirloom tomato production even more difficult and potentially less profitable than conventional production (Rivard and Louws, 2008; Rivard et al., 2010a). With the use of appropriate rootstocks, grafting may be a useful technique for vegetable producers to overcome soilborne pathogens including RKN. Vegetable grafting began in Japan and Korea in the 1920s to manage fusarium wilt (caused by Fusarium oxysporum Smith) in watermelons and is currently widely used in cucurbitaceous and solanaceous crop production in Asian and Mediterranean countries (Lee, 1994; Lee et al., 2010).

Recently, growers and researchers in the United States have begun examining vegetable grafting as an integrated pest management tool for successful vegetable production. Research has focused on grafted seedling production, use, and economics (Kubota et al., 2008; Rivard et al., 2010b); grafting as an alternative to methyl bromide in field production (Freeman et al., 2009); and the use of resistant rootstocks for controlling RKN and soilborne diseases such as bacterial wilt [caused by Ralstonia solanacearum (Smith) Yabuuchi et al.], fusarium wilt, and southern blight (caused by Sclerotium rolfsii Sacc.) (Bausher, 2009; López-Pérez et al., 2006; Rivard and Louws, 2008; Rivard et al., 2010a). With the phase-out of methyl bromide for soil fumigation and the continued rise in demand for organic produce in the United States, the need for alternative disease control methods that do not rely on synthetic biocides has increased (Greene et al., 2009; King et al., 2008; Louws et al., 2010).

Tomato hybrids (Solanum lycopersicum L.) and interspecific tomato hybrids (S. lycopersicum $\times$ S. habrochaites S. Knapp \& D.M. Spooner) have been used worldwide as diseaseresistant rootstocks in grafted tomato production (King et al., 2010). It is unclear how the differences between tomato hybrid rootstocks and interspecific tomato hybrid rootstocks will affect field production of indeterminate heirloom tomatoes. Hence, rootstock evaluations for heirloom tomato production in open-field conditions should involve both types of rootstocks. Field studies conducted in North Carolina demonstrated that southern RKN [M. incognita (Kofoid \& White) Chitwood] could be managed by grafting heirloom tomatoes onto interspecific hybrid rootstocks (Rivard et al., 2010a). However, the inconsistent function of the Mi resistance gene in these rootstocks suggested the need for more examinations of rootstock performance in fields infested with RKN to provide recommendations for effective use of rootstocks. Interest in tomato grafting is emerging among small and organic growers in Florida. The results from the North Carolina studies are promising and suggest that grafting may be applicable in Florida heirloom tomato production. However, 
appropriate rootstocks for Florida conditions need to be determined.

The purpose of this study was to assess heirloom tomato grafting for RKN control under organic production in naturally infested Florida sandy soils. It is hypothesized that grafting onto resistant rootstocks can reduce nematode galling incidence. Tomato hybrid and interspecific tomato hybrid rootstocks were compared with respect to their influence on nematode resistance, crop vigor, and fruit yield.

\section{Materials and Methods}

Scion and rootstock cultivars. Grafted tomato seedlings were produced using certified organic heirloom tomato seed and commercially available non-treated rootstock seeds. The heirloom tomato cultivars Brandywine and Flamme were used as nongrafted controls and as scions (Tomato Fest, Little River, CA). 'Brandywine' (BW) is a large, red, open-pollinated, indeterminate type valued for its excellent flavor and large size, whereas 'Flamme' (FL) is a golf ball-sized, orange, open-pollinated, indeterminate type. 'Multifort' (De Ruiter Seeds, Bergschenhoek, The Netherlands) and 'Survivor' (Takii Seeds, Salinas, CA) were used as rootstocks. 'Multifort' (MU) is an interspecific hybrid ( $S$. lycopersicum $\times S$. habrochaites) and 'Survivor' (SU) is a tomato hybrid (S. lycopersicum). Both rootstocks were chosen for their high resistance to soilborne pathogens and RKNs (Meloidogyne spp.) and vigorous growth habit as claimed by the seed companies.

Transplant production. Rootstock seeds were sown $2 \mathrm{~d}$ before scion seeds on 16 Feb. 2010 and 11 Feb. 2011. Seedlings were grown in Fafard Organic Formula Custom potting

Table 1. Effect of grafting treatments on root-knot nematode galling ratings ${ }^{z}$ of heirloom tomato cultivars Brandywine and Flamme ${ }^{y}$ in 2011.

\begin{tabular}{lrc}
\hline Treatment $^{\mathrm{x}}$ & Organic field & Transitional field \\
\hline & \multicolumn{2}{c}{ Brandywine } \\
NGBW & $7.18 \mathrm{a}$ & $9.30 \mathrm{a}$ \\
BW/BW & $5.86 \mathrm{a}$ & $7.30 \mathrm{~b}$ \\
BW/MU & $1.72 \mathrm{~b}$ & $3.88 \mathrm{c}$ \\
BW/SU & $0.28 \mathrm{~b}$ & $0.54 \mathrm{~d}$ \\
$P$ & $<0.0001$ & $<0.0001$
\end{tabular}

\begin{tabular}{lrl} 
& \multicolumn{2}{c}{ Flamme } \\
NGFL & $6.02 \mathrm{a}$ & $8.06 \mathrm{a}$ \\
FL/FL & $5.28 \mathrm{a}$ & $6.12 \mathrm{a}$ \\
FL/MU & $0.52 \mathrm{~b}$ & $3.48 \mathrm{~b}$ \\
FL/SU & $0.16 \mathrm{~b}$ & $0.00 \mathrm{c}$ \\
$P$ & $<0.0001$ & 0.0001 \\
\hline
\end{tabular}

${ }^{2}$ Root-knot nematode galling index proposed by Zeck (1971); ratings for Spring 2011 trials.

${ }^{y}$ Different letters within a column indicate significant differences at $P \leq 0.05$ by Fisher's least significant difference test; scion cultivars were analyzed separately.

${ }^{\times} \mathrm{NGBW}$ and $\mathrm{NGFL}=$ non-grafted 'Brandywine' and 'Flamme'; BW/BW and FL/FL = self-grafted 'Brandywine' and 'Flamme'; BW/MU and FL/MU = 'Brandywine' and 'Flamme' grafted onto the interspecific tomato hybrid rootstock 'Multifort'; $\mathrm{BW} / \mathrm{SU}$ and $\mathrm{FL} / \mathrm{SU}=$ 'Brandywine' and 'Flamme' grafted onto the tomato hybrid rootstock 'Survivor'. mix (Apopka, FL) using 128-cell-count Speedling Flats (Sun City, FL). At the four to five true leaf stage, seedlings were tubegrafted. Grafting procedures were adapted from Rivard and Louws (2006) in which young seedlings are grafted and held together using $2.0-\mathrm{mm}$ or $1.5-\mathrm{mm}$ silicone clips (Hydro-Gardens, Colorado Springs, CO). Grafting took place $34 \mathrm{~d}$ and $28 \mathrm{~d}$ after scions were sown for 2010 and 2011, respectively. The grafted seedlings were then placed in a temperature- and humidity-controlled walkin cooler at $25^{\circ} \mathrm{C}$ and $\approx 95 \%$ RH with no light for $24 \mathrm{~h}$. Thereafter, the grafted seedlings were gradually exposed to light, and humidity was reduced for $6 \mathrm{~d}$ until the seedlings healed. Grafted seedlings were then transported to the greenhouse before transplanting into the field.

Field trials. Three field trials were conducted at the University of Florida Plant Science Research and Education Unit in Citra, FL. One trial was conducted in the Spring of 2010, whereas two were conducted in the Spring of 2011. In both years, one trial was grown on certified organic land following the rules outlined by the National Organic Program (U.S. Department of Agriculture, Agricultural Marketing Service, 2002). The organic research land was certified by Quality Certification Services, Gainesville, FL. Organic yellow squash (Cucurbita pepo L.), an excellent host for RKN (Wang et al., 2004), was grown during the 2010 Fall growing season to encourage a more uniform natural RKN infestation and increase RKN numbers for the 2011 organic field trial. Additionally, in the Spring of 2011, a trial was conducted on a site with a history of continuous nematode infestation that had been managed conventionally in previous years. Plants used in this trial were produced and grown following organic practices. This trial was designed to reflect growing conditions during a typical 3-year transition period from conventional to organic production. The soil type found in all three field trials is Candler sand, 0 to $5 \%$ slopes, hyperthermic, uncoated Typic Quartzipsamments with a $\mathrm{pH}$ of 6.0 .

In all trials, there were eight treatments consisting of: non-grafted and self-grafted scion controls for 'Brandywine' (NGBW,
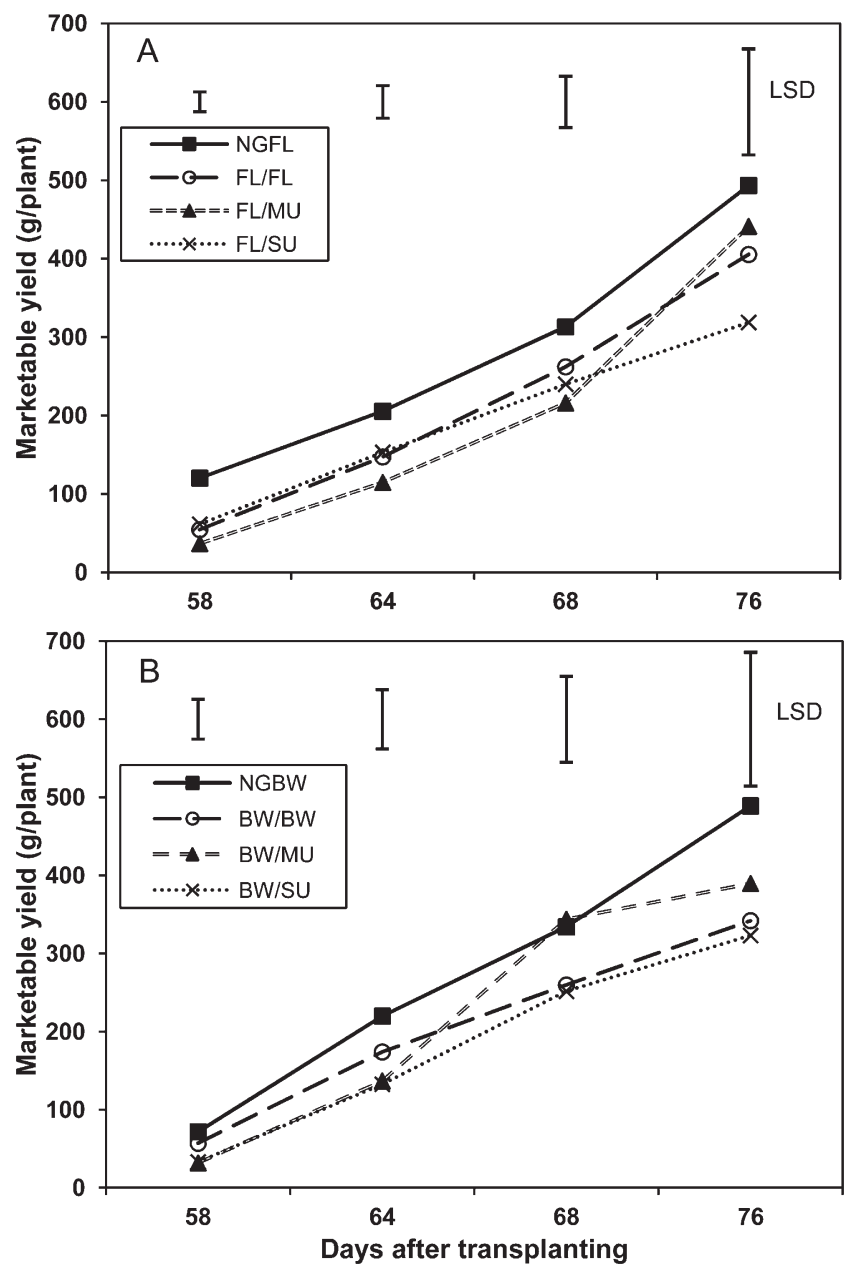

Fig. 1. Cumulative marketable yield for non-grafted and grafted heirloom tomato cultivars Flamme (A) and Brandywine (B) from the organic field trial conducted in 2010. Each harvest was analyzed using a oneway analysis of variance and means were separated by Fisher's least significant difference (LSD) test. LSD bars represent the least significant difference at $P \leq 0.05 . \mathrm{NGBW}$ and NGFL $=$ non-grafted 'Brandywine' and 'Flamme'; BW/BW and FL/FL = self-grafted 'Brandywine' and 'Flamme'; BW/MU and FL/MU = 'Brandywine' and 'Flamme' grafted onto the interspecific tomato hybrid rootstock 'Multifort'; BW/SU and $\mathrm{FL} / \mathrm{SU}=$ 'Brandywine' and 'Flamme' grafted onto the tomato hybrid rootstock 'Survivor'. 
BW/BW) and 'Flamme' (NGFL, FL/FL) and the scion-rootstock combinations including 'Brandywine' and 'Flamme' grafted onto the rootstocks 'Multifort' (BW/MU, FL/MU) and 'Survivor' (BW/SU, FL/SU). The seedlings were transplanted on 10 Apr. 2010 and 2 Apr. 2011. A randomized complete block design was used with five blocks (replications). In the 2010 trial, there were 12 plants per treatment in each block. In 2011, there were 15 plants per treatment in the organic field and eight plants per treatment in the transitional field. In all three trials, the in-row plant spacing was $0.46 \mathrm{~m}$ with $1.83 \mathrm{~m}$ between row centers. The plants were grown in raised beds with black plastic mulch and drip irrigation. A preplant application of Nature Safe organic fertilizer $10 \mathrm{~N}-0.9 \mathrm{P}-6.6 \mathrm{~K}$ (Cold Spring, KY) was made at the rate of $179 \mathrm{~kg} \mathrm{~N} / \mathrm{ha}$. Supplemental liquid fertilizer applications were injected into the drip system once a week at a rate of $0.45 \mathrm{~kg} \mathrm{~N} / \mathrm{ha}$ throughout the season using Neptune's Harvest $2 \mathrm{~N}-1.3 \mathrm{P}-0.8 \mathrm{~K}$ (Gloucester, MA). Supplemental calcium was also supplied once a week through injection at a rate of $0.10 \mathrm{~kg} \cdot \mathrm{ha}^{-1}$ calcium with Calplex (Botanicare, Chandler, AZ). All nutrient inputs were approved by the Organic Materials Review Institute (OMRI, Eugene, OR) for use in certified organic production. The plants were staked and trellised as needed throughout the season following the stake and weave system common to Florida tomato production (Olson et al., 2011).

Nematode galling. Assessments of nematode infestation on plant roots were conducted after the final harvest. On 13 July 2010 and 30 June 2011, roots of five plants per treatment in each block in the organic fields and three plants per treatment in each block in the transitional field were assessed for nematode galls. The rating scheme proposed by Zeck (1971) that estimates nematode infestation levels on a plant was used. This scheme is a scale from 0 to 10 $(0=$ no galling, $10=$ plant and roots are dead $)$. Three researchers assessed each plant individually and then the ratings were averaged. In addition, two nematode samples from each field were submitted to the University of Florida Nematode Assay Laboratory for identification of species.

Fruit yield. Tomato harvests began $58 \mathrm{~d}$ after transplanting (DAT) in 2010 and 63 DAT in 2011. In 2010, there were four harvests occurring on 7, 13, 17, and 25 June. In 2011, there were six harvests in the organic field and five harvests in the transitional field occurring on $4,8,13,16,22$ (organic only), 23 (transitional only), and 28 (organic only) June. Fruit were harvested at the breaker stage and were graded and weighed at each harvest. Noncharacteristic fruit and those exhibiting blossom end rot, catfacing, splitting, and insect/ disease damage were also counted and weighed for calculation of non-marketable yield.

Crop vigor. The aboveground portion of one representative plant per treatment was destructively harvested in each block after the final harvest on 25 June 2010 and 30 June 2011 in the organic fields. Leaf area was measured using a LI-COR area meter (LI-3100,
Lincoln, NE). After recording leaf area, each plant was dried in a forced-air drying room at $75^{\circ} \mathrm{C}$ for $5 \mathrm{~d}$ and weighed for aboveground biomass.

Statistical analyses. Data analyses were performed for both scion cultivars separately using the GLIMMIX procedure of SAS Version 9.2 (SAS Institute, Cary, NC). All yield, crop vigor, and nematode galling data were analyzed using a one-way analysis of variance with multiple comparisons conducted using Fisher's least significant difference test at $P \leq 0.05$.

\section{Results and Discussion}

Nematode galling. In the 2010 field trial, no RKN galls were observed on the tomato plants regardless of the treatment. Yellow squash was grown during the Fall of 2010 in the organic field to build a natural RKN population for the Spring 2011 season. RKN trials had been conducted in the transitional field for greater than 10 years and there was a wellestablished RKN population in that site.

In the 2011 trials, almost all treatments showed RKN galling despite the use of rootstocks. However, RKN galling index ratings were significantly lower ( $P \leq 0.0001)$ in both fields for tomatoes grafted onto 'Survivor' and 'Multifort' compared with the non- and selfgrafted 'Brandywine' and 'Flamme' treatments (Table 1). The nematode species found in both fields was identified by the Nematode Assay Laboratory as M. javanica (Treub) Chitwood using species-specific polymerase chain reaction primers (Dong et al., 2001). In the organic field, the hybrid rootstocks performed similarly and significantly reduced root galling compared with the non-grafted and self-grafted scions by $\approx 80.8 \%$. In the transitional field, both rootstocks significantly reduced root galling for both scions in comparison with the non- and self-grafted scion treatments. However, the rootstock 'Survivor' led to the lowest galling ratings for both scion cultivars (Table 1). Compared with non-grafted scions, the root galling reduction by 'Survivor' (97.1\%) was significantly greater than that by 'Multifort' $(57.6 \%)$. The self-grafted 'Brandywine' treatment had significantly lower galling index ratings than the non-grafted 'Brandywine' treatment. This reduced galling in the transitional field was unexpected and the cause is unclear. It may be
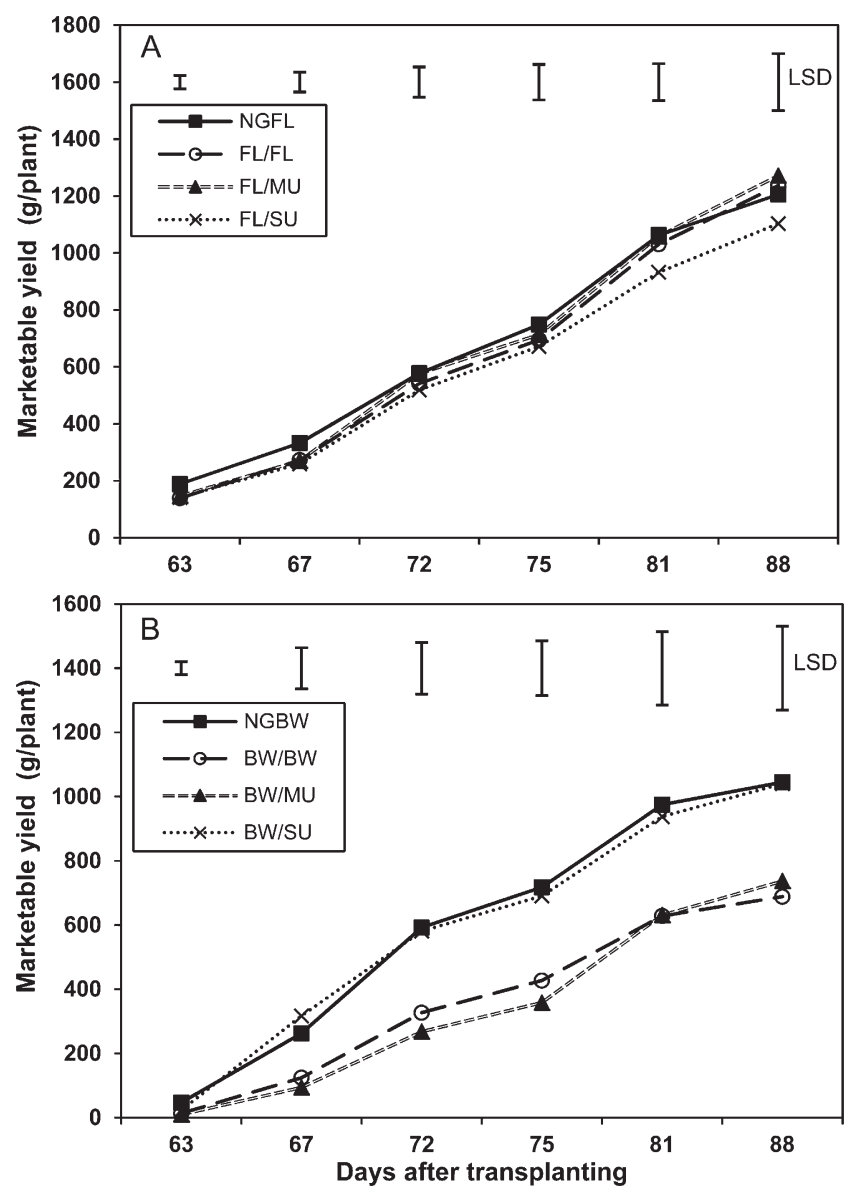

Fig. 2. Cumulative marketable yield for non-grafted and grafted heirloom tomato cultivars Flamme (A) and Brandywine (B) from the organic field trial conducted in 2011. Each harvest was analyzed using a oneway analysis of variance and means were separated by Fisher's least significant difference (LSD) test. LSD bars represent the least significant difference at $P \leq 0.05$. NGBW and NGFL $=$ non-grafted 'Brandywine' and 'Flamme'; BW/BW and FL/FL = self-grafted 'Brandywine' and 'Flamme'; BW/MU and FL/MU = 'Brandywine' and 'Flamme' grafted onto the interspecific tomato hybrid rootstock 'Multifort'; BW/SU and $\mathrm{FL} / \mathrm{SU}=$ 'Brandywine' and 'Flamme' grafted onto the tomato hybrid rootstock 'Survivor'. 
that for the scion 'Brandywine', the act of grafting promoted a defense response, which resulted in reduced galling ratings, but further investigation will be required to elucidate a cause. Intermediate levels of disease resistance and yield in self-grafted tomatoes have been reported in previous research (Rivard, 2006).

The RKN galling ratings were generally higher in the transitional field than the organic field, suggesting a more severe infestation (Table 1). This trend was observed with 'Multifort' but not with 'Survivor'. Under different field infestation levels, the high resistance to RKN was consistent when the two heirloom tomato cultivars were grafted onto 'Survivor'. In contrast, the resistance conferred by 'Multifort' appeared to break when the soil RKN infestation increased. In this study, 'Multifort' performed similarly to 'Beaufort' and 'Maxifort', which were assessed by Rivard et al. (2010a). These three interspecific tomato hybrid rootstocks were released by the same seed company and tend to exhibit tolerance to $\mathrm{RKN}$ rather than resistance. RKN resistance is conferred by the $M i-1$ gene that was introduced into commercial tomato rootstocks and cultivars from the wild tomato relative Solanum peruvianum L. (López-Pérez et al., 2006; Medina-Filho and Stevens, 1980). 'Beaufort' carries the Mi gene but exhibited tolerance to RKN (M. incognita) rather than resistance because RKN populations reproduced and increased on the 'Beaufort' rootstock, whereas the fruit yield of a susceptible tomato cultivar was improved when it was grafted onto 'Beaufort' (LópezPérez et al., 2006). Similarly, Cortada et al. (2008) detected the Mi resistance gene in 'Beaufort' and 'Maxifort', but both cultivars demonstrated susceptibility to $M$. javanica infestation in phenotypic assays. Our relatively high galling ratings for the interspecific rootstock 'Multifort' and lower galling ratings for the tomato hybrid rootstock 'Survivor' were consistent with the study by López-Pérez et al. (2006) in which 'Hypeel45', a processing tomato cultivar with $\mathrm{Mi}$-gene resistance, was found to have lower galling ratings than 'Beaufort' (López-Pérez et al., 2006).

According to a pot study by Devran et al. (2010), the root galling index for 'Beaufort' plants in response to $M$. incognita at $32{ }^{\circ} \mathrm{C}$ soil temperature was significantly higher than that at $24{ }^{\circ} \mathrm{C}$ soil temperature. In contrast, some other studies did not reveal a clear relationship between soil temperature and RKN susceptibility of 'Beaufort' and 'Maxifor' rootstocks (López-Pérez et al., 2006; Rivard et al., 2010a). In our study, the average soil temperatures at $10 \mathrm{~cm}$ depth were above $28{ }^{\circ} \mathrm{C}$ during May and June 2011 with the maximum reaching $36-37^{\circ} \mathrm{C}$. However, the high temperature sensitivity of $\mathrm{Mi}$-mediated resistance to RKN may not have been seen in our study, because grafting with 'Multifort' resulted in differential responses to $M$. javanica infestation in organic and transitional fields during the same production season.

Fruit yield. The harvesting periods in this study were much shorter than some of the previous studies on organic heirloom tomato
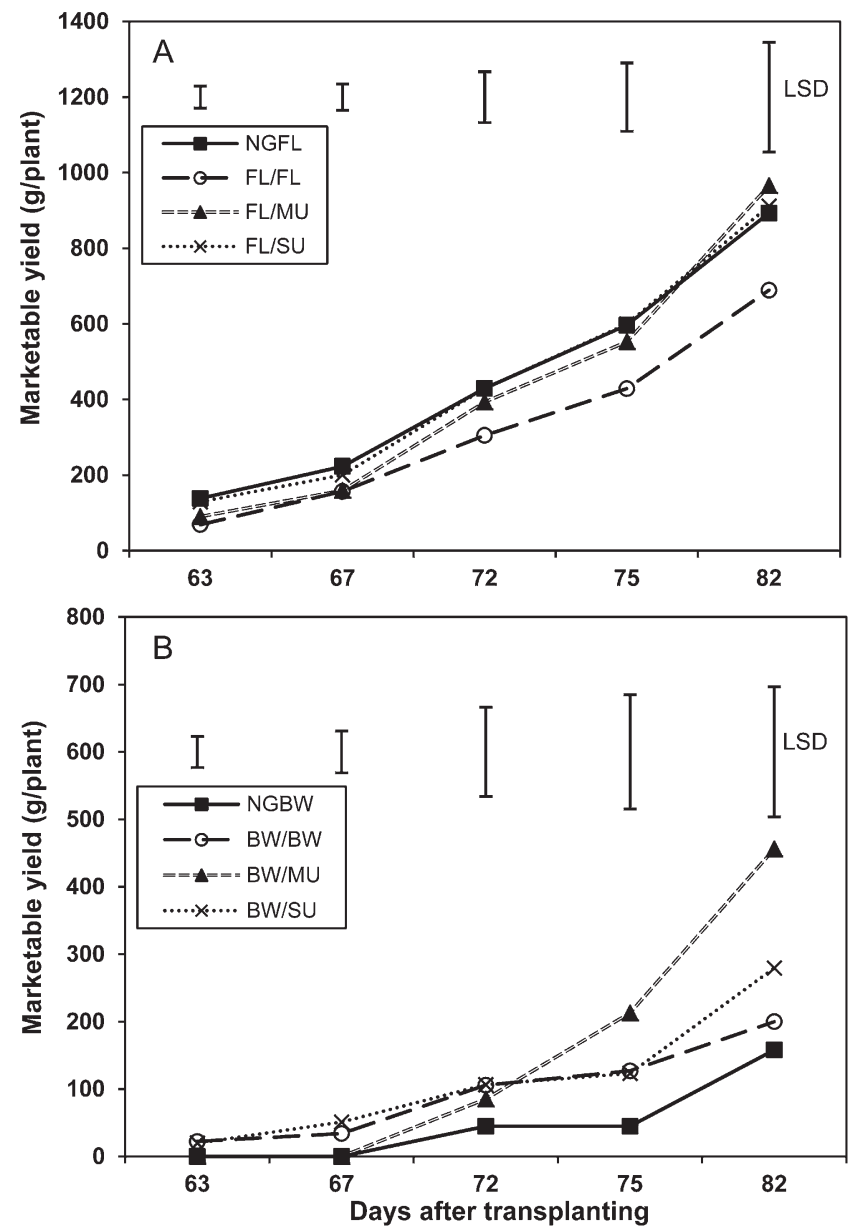

Fig. 3. Cumulative marketable yield for non-grafted and grafted heirloom tomato cultivars Flamme (A) and Brandywine (B) from the 2011 trial in a conventional field under transition to organic. Each harvest was analyzed using a one-way analysis of variance and means were separated by Fisher's least significant difference (LSD) test. LSD bars represent the least significant difference at $P \leq 0.05$. NGBW and NGFL = non-grafted 'Brandywine' and 'Flamme'; BW/BW and FL/FL = self-grafted 'Brandywine' and 'Flamme'; BW/MU and FL/MU = 'Brandywine' and 'Flamme' grafted onto the interspecific tomato hybrid rootstock 'Multifort'; BW/SU and FL/SU = 'Brandywine' and 'Flamme' grafted onto the tomato hybrid rootstock 'Survivor'.

Table 2. Effect of grafting treatments on leaf area and aboveground biomass of heirloom tomato cultivars Brandywine and Flamme. ${ }^{z}$

\begin{tabular}{|c|c|c|c|c|}
\hline \multirow[b]{2}{*}{ Treatment ${ }^{\mathrm{w}}$} & \multicolumn{2}{|c|}{2010} & \multicolumn{2}{|c|}{2011} \\
\hline & Leaf area ${ }^{y}\left(\mathrm{~cm}^{2}\right)$ & Biomass $^{\mathrm{x}}$ (g/plant) & Leaf $\operatorname{area}^{\mathrm{y}}\left(\mathrm{cm}^{2}\right)$ & Biomass $^{x}$ (g/plant) \\
\hline & \multicolumn{4}{|c|}{ Brandywine } \\
\hline NGBW & $3,144.9 \mathrm{~b}$ & $176.6 \mathrm{~b}$ & $13,136.7 \mathrm{ab}$ & $349.4 \mathrm{ab}$ \\
\hline $\mathrm{BW} / \mathrm{BW}$ & $2,925.9 \mathrm{~b}$ & $171.2 \mathrm{~b}$ & $11,343.4 \mathrm{~b}$ & $316.4 \mathrm{~b}$ \\
\hline $\mathrm{BW} / \mathrm{MU}$ & $5,548.8 \mathrm{a}$ & $238.5 \mathrm{a}$ & $18,299.8 \mathrm{a}$ & $477.7 \mathrm{a}$ \\
\hline $\mathrm{BW} / \mathrm{SU}$ & $2,649.0 \mathrm{~b}$ & $158.8 \mathrm{~b}$ & $9,618.2 \mathrm{~b}$ & $280.7 \mathrm{~b}$ \\
\hline \multirow[t]{2}{*}{$P$} & 0.019 & 0.046 & 0.018 & 0.031 \\
\hline & \multicolumn{4}{|c|}{ Flamme } \\
\hline NGFL & $2420.3 \mathrm{~b}$ & $172.4 \mathrm{a}$ & $6875.0 \mathrm{~b}$ & $248.3 \mathrm{~b}$ \\
\hline FL/FL & $2358.2 \mathrm{~b}$ & $168.4 \mathrm{a}$ & $7999.9 \mathrm{~b}$ & $277.6 \mathrm{~b}$ \\
\hline $\mathrm{FL} / \mathrm{MU}$ & $3833.5 \mathrm{a}$ & $203.7 \mathrm{a}$ & $10459.6 \mathrm{a}$ & $383.0 \mathrm{a}$ \\
\hline $\mathrm{FL} / \mathrm{SU}$ & $1729.2 \mathrm{~b}$ & $164.6 \mathrm{a}$ & $6927.5 \mathrm{~b}$ & $271.5 \mathrm{~b}$ \\
\hline$P$ & 0.014 & 0.242 & 0.011 & 0.041 \\
\hline
\end{tabular}

${ }^{2}$ Different letters within a column indicate significant differences at $P \leq 0.05$ by Fisher's least significant difference test; scion cultivars were analyzed separately.

${ }^{\mathrm{y}}$ Mean total leaf area per plant.

${ }^{x}$ Mean total aboveground dry weight per plant.

"NGBW and NGFL = non-grafted 'Brandywine' and 'Flamme'; BW/BW and FL/FL = self-grafted 'Brandywine' and 'Flamme'; BW/MU and FL/MU = 'Brandywine' and 'Flamme' grafted onto the interspecific tomato hybrid rootstock 'Multifort'; $\mathrm{BW} / \mathrm{SU}$ and $\mathrm{FL} / \mathrm{SU}=$ 'Brandywine' and 'Flamme' grafted onto the tomato hybrid rootstock 'Survivor'. 
production (e.g., Rivard and Louws, 2008) and therefore the relatively low range of marketable yields in this study was not surprising. Meanwhile, 'Brandywine' has been shown as a low-yielding heirloom tomato cultivar (Kline and Nitzsche, 2005; Williams et al., 2005).

For the cultivar Flamme in 2010, the grafted plants produced significantly lower marketable yields than the non-grafted control for the first two harvests. However, there were no significant differences in total marketable yield for the 'Flamme' treatments in 2010 and 2011 (Figs. 1A, 2A, and 3A). Reduced early yields may be an effect of the grafting process. Khah et al. (2006) reported greater early yields for non-grafted plants and hypothesized that the stress associated with grafting and healing delayed flowering in grafted plants. In our study, the effect of grafting on early yields was inconsistent and varied with scion cultivars and growing seasons. Surprisingly, although 'Flamme' was susceptible to RKN and the infestation was significantly decreased in plants grafted onto resistant rootstocks, total marketable fruit yields did not differ significantly between non-grafted and grafted treatments.

There were no significant differences in marketable yield at any harvest dates for the scion 'Brandywine' in 2010 (Fig. 1B). In 2011, there was variability in marketable yields for the 'Brandywine' treatments between the organic and transitional fields. In the organic field, the NGBW and BW/SU treatments produced significantly higher total marketable yields than the BW/BW and BW/MU treatments (Fig. 2B). However, in the transitional field, BW/MU demonstrated significantly higher total marketable yields than the BW/ BW and NGBW treatments (Fig. 3B). The $\mathrm{BW} / \mathrm{SU}$ treatment resulted in statistically similar yields to all other 'Brandywine' treatments in the transitional field. Overall, total fruit yields showed trends similar to marketable fruit yields (data not shown).

Some of these yield differences in 2011 may be attributed to the presence of RKN. With no RKN pressure in the 2010 trial, there were no differences in total marketable yield with either scion cultivar. However, with high RKN pressure in the 2011 transitional field, the highest marketable yield for the scion 'Brandywine' was achieved when grafted onto 'Multifort'. Our results were consistent with the study by López-Pérez et al. (2006), in which significantly higher tomato fruit yield was observed with resistant rootstocks at high RKN ( $M$. incognita) densities. According to Rivard et al. (2010a), total and marketable tomato fruit yields were higher on interspecific hybrid rootstocks under severe RKN and southern blight disease pressure. In contrast, grafting did not exhibit any significant effect on heirloom tomato yield under low disease pressure and it was unclear if grafting onto interspecific hybrid rootstocks would be beneficial in such circumstances (Rivard and Louws, 2008).

López-Pérez et al. (2006) did not detect a yield response with tomato plants grafted onto the 'Beaufort' rootstock at intermediate populations of RKN. In our study, NGBW and BW/SU performed similarly at intermediate levels of RKN infestation in the 2011 organic field trial, whereas $\mathrm{BW} / \mathrm{BW}$ and $\mathrm{BW} /$ MU yielded significantly less marketable fruit. It is unclear why tomato yield was reduced for BW/MU because it showed significantly lower root galling ratings compared with NGBW and BW/BW and did not differ significantly from BW/SU in terms of RKN resistance. This response could be related to the genetic background of 'Multifort'. This rootstock was developed from a breeding line of greenhouse rootstocks aimed at enhanced crop vigor and extended growing seasons in addition to disease resistance. It could be that the increased vigor and vegetative growth that is useful in greenhouse conditions had a deleterious effect on 'Brandywine' fruit yield in the shorter field-growing season. More studies are warranted to examine the influence of vigorous interspecific hybrid rootstocks on the yield of indeterminate cultivars grown in field production systems. New rootstocks
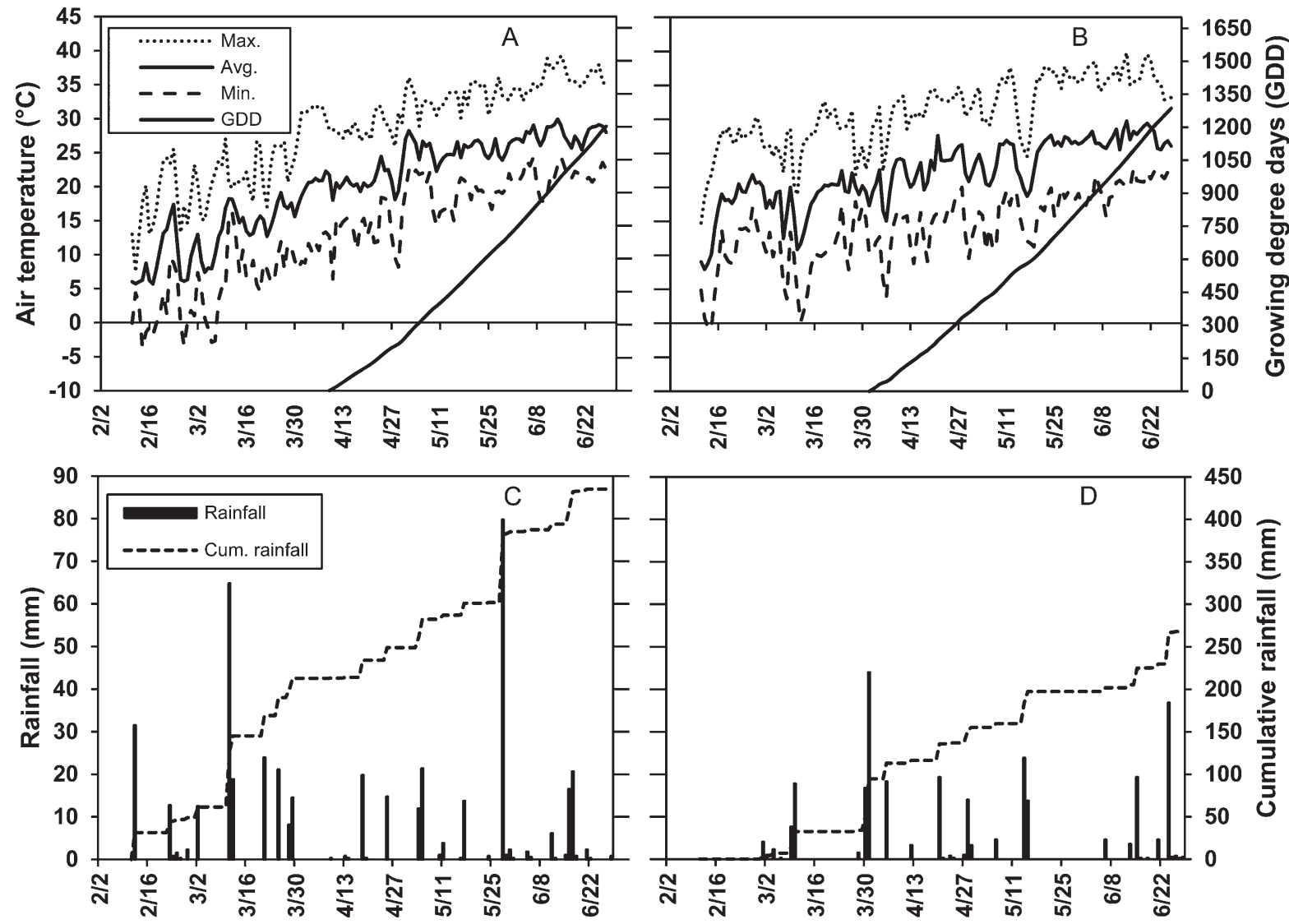

Fig. 4. Maximum, average, minimum daily air temperatures and cumulative growing degree-days (GDD, base temperature $10^{\circ} \mathrm{C}$, with 0 GDD at the day before transplanting) and daily and cumulative rainfall for 2010 (A, C) and 2011 (B, D). Data source: Florida Automated Weather Network (<http:// fawn.ifas.ufl.edu/>). 
developed for open-field production would help establish more integrated pest management techniques for growers not using greenhouses or high tunnels (Kubota et al., 2008).

Crop vigor. Rootstock effects were also observed in leaf area and aboveground biomass evaluations. When grafted to the rootstock 'Multifort', the scion 'Brandywine' produced significantly greater leaf area and aboveground biomass than NGBW, BW/BW, and $\mathrm{BW} / \mathrm{SU}$ in 2010. In the 2011 trial, the leaf area and aboveground biomass of BW/MU were significantly greater than that of $\mathrm{BW} / \mathrm{BW}$ and $\mathrm{BW} / \mathrm{SU}$, but there was no significant difference between BW/MU and NGBW (Table 2). The scion 'Flamme' treatment combinations performed similarly to the 'Brandywine' treatment combinations. For both years, FL/MU produced significantly greater leaf area than NGFL, FL/FL, and FL/SU. In 2011, aboveground biomass was significantly greater for FL/MU than all other 'Flamme' treatments (Table 2).

The interspecific rootstock 'Maxifort' has been shown to increase leaf area for the heirloom tomato 'Cuore di Bue' when grown in a greenhouse (Di Gioia et al., 2010). The effect of the rootstock should be carefully examined when grafting is used for a specific growing condition. King et al. (2010) pointed out that disease management might be considered the most important purpose for growing grafted heirloom tomatoes by organic growers and using more vigorous rootstocks might adversely affect crop yields. The interspecific hybrid rootstock 'Multifort' used in this experiment is similar to 'Maxifort' in terms of vigorous growth. It may be advantageous to use these vigorous rootstocks for greenhouse tomato production where season extension is strongly emphasized; however, when used in the open field, this increase in vegetative growth may not be beneficial. This is the result of the shorter field production cycle in Florida where frost in early spring and late fall and hot, humid conditions in summer can limit tomato production seasons. On the other hand, the increased vigor provided by 'Multifort' might be related to the tolerance exhibited by this rootstock to high populations of RKN.

Despite the presence of RKN in 2011, both yield and crop vigor for all treatments were greater in 2011 than those from 2010 (Figs. 1, 2, and 3; Tables 1 and 2). Before transplanting in 2010 (February to March), the weather was much colder than the same time period in 2011 (Fig. 4A-B). These cooler temperatures likely reduced the mineralization of the preplant-applied organic fertilizers and subsequent crop performance. The 2010 growing season was $11 \mathrm{~d}$ shorter than 2011 as a result of delayed planting and an increased accumulation of moisture. There was $167 \mathrm{~mm}$ more rain in 2010 than in 2011 (Fig. 4C-D) and an increased incidence of bacterial spot disease (caused by Xanthomonas campestris) in 2010. The variation of seasonal conditions and crop productivity was also observed by others conducting tomato research previously in Citra, FL (Zotarelli et al., 2009). The drier and more mild 2011 season was more advantageous for growing irrigated tomatoes.

\section{Conclusions}

Interest in vegetable grafting is growing in the United States; therefore, more research is needed to determine the rootstock effects on crop performance under site-specific conditions and different production systems. With respect to controlling $\mathrm{RKN}$, our study indicated the interspecific hybrid rootstock 'Multifort' tended to exhibit tolerance under severe RKN pressure because the tomato hybrid rootstock 'Survivor' resulted in a greater reduction of root galling than the interspecific tomato hybrid rootstock. In a field with intermediate levels of RKN infestation, the two types of rootstocks exhibited similar levels of effectiveness in reducing root galling. Interestingly, there was no clear relationship between root galling and tomato yields. Moreover, the two heirloom tomato scions 'Brandywine' and 'Flamme' exhibited differential responses to the two rootstocks used in terms of yield performance. When assessing whether to use grafted tomato plants for RKN management, growers need to consider the severity of the RKN infestation, the growing system, and the scion and rootstock cultivars to be used.

\section{Literature Cited}

Bausher, M.G. 2009. Commercial tomato rootstock performance when exposed to natural populations of root-knot nematodes in Florida. HortScience 44:1021 (abstr.).

Bland, S.E. 2005. Consumer acceptability of heirloom tomatoes. MS thesis, University of Georgia, Athens, GA.

Cortada, L., F.J. Sorribas, C. Ornat, I. Kaloshian, and S. Verdejo-Lucas. 2008. Variability in infection and reproduction of Meloidogyne javanica on tomato rootstocks with the $\mathrm{Mi}$ resistance gene. Plant Pathol. 57:1125-1135.

Devran, Z., M.A. Söğüt, and N. Mutlu. 2010 Response of tomato rootstocks with the $M i$ resistance gene to Meloidogyne incognita race 2 at different soil temperatures. Phytopathol. Mediterr. 49:11-17.

Di Gioia, F., F. Serio, D. Buttaro, O. Ayala, and P. Santamaria. 2010. Influence of rootstock on vegetative growth, fruit yield and quality in 'Cuore di Bue', an heirloom tomato. J. Hort. Sci. Biotechnol. 85:477-482.

Dong, K., R.A. Dean, B.A. Fortnum, and S.A. Lewis. 2001. Development of PCR primers to identify species of root-knot nematodes: Meloidogyne arenaria, M. hapla, M. incognita and M. javanica. Nematropica 31:271-280.

Freeman, J., S. Rideout, and A. Wimer. 2009 Performance of grafted tomato seedlings in open field production. Ann. Int. Res. Conf. Methyl Bromide Alternatives and Emissions Reductions. Methyl Bromide Alternatives Outreach, San Diego, CA. 22 Nov. 2011. <http:// mbao.org/2009/Proceedings/045FreemanJG rafted\%20tomato\%20MBAO.pdf>.

Greene, C., C. Dimitri, B.H. Lin, W. McBride, L. Oberholtzer, and T. Smith. 2009. Emerging issues in the U.S. organic industry. EIB-55. U.S. Dept. Agr. Econ. Res. Serv., Washington, DC.
Jordan, J.A. 2007. The heirloom tomato as cultural object: Investigating taste and space. Sociol. Ruralis 47:20-41.

Khah, E.H., E. Kakava, A. Mavromatis, D. Chachalis, and C. Goulas. 2006. Effect of grafting on growth and yield of tomato (Lycopersicon esculentum Mill.) in greenhouse and open-field. J. Appl. Hort. 8:3-7.

King, S.R., A.R. Davis, W. Liu, and A. Levi. 2008. Grafting for disease resistance. HortScience 43:1673-1676.

King, S.R., A.R. Davis, X. Zhang, and K. Crosby 2010. Genetics, breeding and selection of rootstocks for Solanaceae and Cucurbitaceae. Sci. Hort. 127:106-111.

Klee, H.J. 2010. Improving the flavor of fresh fruits: Genomics, biochemistry, and biotechnology. New Phytol. 187:44-56.

Kline, W. and P. Nitzsche. 2005. Heirloom tomato cultivar evaluation for the New Jersey market. HortScience 40:1031 (abstr.)

Kubota, C., M.A. McClure, N. Kokalis-Burelle, M.G. Bausher, and E.N. Rosskopf. 2008. Vegetable grafting: History, use, and current technology status in North America. HortScience 43:1664-1669.

Lee, J.M. 1994. Cultivation of grafted vegetables. I. Current status, grafting methods, and benefits. HortScience 29:235-239.

Lee, J.M., C. Kubota, S.J. Tsao, Z. Bie, P. Hoyos Echevarria, L. Morra, and M. Oda. 2010. Current status of vegetable grafting: Diffusion, grafting techniques, automation. Sci. Hort. 127:93-105.

López-Pérez, J.A., M. Le Strange, I. Kaloshian, and A.T. Ploeg. 2006. Differential response of $M i$ gene-resistant tomato rootstocks to root-knot nematodes (Meloidogyne incognita). Crop Prot. 25:382-388.

Louws, F.J., C.L. Rivard, and C. Kubota. 2010. Grafting fruiting vegetables to manage soilborne pathogens, foliar pathogens, arthropods and weeds. Sci. Hort. 127:127-146.

Medina-Filho, H.P. and M.A. Stevens. 1980. Tomato breeding for nematode resistance: Survey of resistant varieties for horticultural characteristics and genotype of acid phosphates. Acta Hort. 100:383-393.

Olson, S.M., W.M. Stall, G.E. Vallad, S.E. Webb, S.A. Smith, E.H. Simonne, E.J. McAvoy, B.M. Santos, and M. Ozores-Hampton. 2011. Tomato production in Florida, p. 309-332. In: Olson, S.M. and B.M. Santos (eds.). Vegetable production handbook for Florida. Vance Publishing Corporation, Lincolnshire, IL.

Rivard, C. and F. Louws. 2006. Grafting for disease resistance in heirloom tomatoes. North Carolina Coop. Ext. Serv. Bul. Ag-675. North Carolina State University, Raleigh, NC.

Rivard, C.L. 2006. Grafting tomato to manage soilborne diseases and improve yield in organic production systems. MS thesis, North Carolina State University, Raleigh, NC.

Rivard, C.L. and F.J. Louws. 2008. Grafting to manage soilborne diseases in heirloom tomato production. HortScience 43:21042111.

Rivard, C.L., S. O'Connell, M.M. Peet, and F.J. Louws. 2010a. Grafting tomato with interspecific rootstock to manage diseases caused by Sclerotium rolfsii and southern root-knot nematode. Plant Dis. 94:1015-1021.

Rivard, C.L., O. Sydorovych, S. O'Connell, M.M. Peet, and F.J. Louws. 2010b. An economic analysis of two grafted tomato transplant production systems in the United States. HortTechnology 20:794-803. 
Roberts, P.A., W.C. Matthews, Jr., and J.D. Ehlers. 2005. Root-knot nematode resistant cowpea cover crops in tomato production systems. Agron. J. 97:1626-1635.

Sasser, J.N. 1980. Root-knot nematodes: A global menace to agriculture. Plant Dis. 64: 36-41.

U.S. Department of Agriculture, Agricultural Marketing Service. 2002. Code of Federal Regulations, Title 7, Part 205. National Organic Program.
U.S. Dept Agr., Washington, DC. 8 Aug. 2011. $<$ http://www.ams.usda.gov/AMSv1.0/getfile? dDocName $=$ STELDEV3004452 $>$.

Wang, K.H., R. McSorley, and R.N. Gallaher 2004. Effect of Crotalaria juncea amendment on squash infected with Meloidogyne incognita. J. Nematol. 36:290-296.

Williams, D.R., C.R. Andersen, S.E. Eaton, and L.W. Martin. 2005. Tomato cultivar evaluation in Arkansas. HortScience 40:890 (abstr.).
Zeck, W.M. 1971. A rating scheme for field evaluation of root-knot nematode infestations. Pflanzenschutz-Nachrichten Bayer 24:141144.

Zotarelli, L., J.M. Scholberg, M.D. Dukes, R. Muñoz-Carpena, and J. Icerman. 2009. Tomato yield, biomass accumulation, root distribution and irrigation water use efficiency on a sandy soil, as affected by nitrogen rate and irrigation scheduling. Agr. Water Mgt. 96:23-34. 